\title{
KEMAMPUAN MEMAHAMI STRUKTUR TEKS EKSPOSISI SISWA KELAS VIII SMP NEGERI 2 WADAGA KABUPATEN MUNA BARAT \\ Sulastin $^{1}$, Haerun Ana, ${ }^{2}$ dan Sahlan, 3 pbsi.fkip.uho@gmail.com
}

\author{
1,2,3, Jurusan Pendidikan Bahasa dan Sastra Indonesia, \\ Fakultas Keguruan dan Ilmu Pendidikan, Universitas Halu Oleo \\ Kampus Hijau Bumi Tridharma Anduonohu, Kendari, Indonesia
}

\begin{abstract}
ABSTRAK
Kemampuan Memahami Isi Teks Eksposisi Siswa Kelas VIII SMP Negeri 2 Wadaga Kabupaten Muna Barat" penelitian ini pentingnya untuk melihat kembali kemampuan siswa apakah telah mampu menyerap materi memahami isi teks eksposisi atau belum. Tujuan penelitian ini adalah untuk mendeskripsikan kemampuan memahami isi teks eksposisi siswa kelas VIII SMP Negeri 2 Wadaga Kabupaten Muna Barat. Jenis penelititan ini tergolong dalam penelitian sekolah sebab peneliti turun langsung ke lokasi penelitian (sekolah) untuk mengumpulkan data sesuai dengan masalah penelitian. Populasi dalam penelitian ini adalah keseluruhan siswa kelas VIII SMP Negeri 2 Wadaga Kabupaten Muna Barat yang terdiri atas 51 orang siswa, yang tersebar dalam 2 kelas. Dan sampel dalam penelitian ini adalah keseluruhan siswa kelas VIII SMP Negeri 2 Wadaga Kabupaten Muna Barat. Teknik pengumpulan data yang digunakan dalam penelitian ini adalah bentuk tes esai tertulis, yaitu dengan menugaskan siswa untuk memahami isi teks eksposisi yang telah dibaca. Hasil penelitian ini menunjukan bahwa dari 51 orang responden siswa kelas VIII SMP Negeri 2 Wadaga Kabupaten Muna Barat, terdapat 39 orang siswa $(76,47 \%)$ masuk kategori mampu secara individual dalam memahami isi teks eksposisi, dan sebanyak 12 orang siswa $(23,52 \%)$ masuk kategori belum mampu dalam memahami isi teks eksposisi. Secara klasikal dapat dikatakan bahwa kemampuan memahami isi teks eksposisi siswa kelas VIII SMP Negeri 2 Wadaga Kabupaten Muna Barat masuk kategori belum mampu secara klasikal. Dikatakan demikian karena kemampuan siswa hanya mencapai 76,47\% belum mencapai kriteria ketuntasan klasikal yaitu 85\%. Jika dilihat dari setiap aspek penilaian kemampuan memahami isi teks eksposisi siswa kelas VIII SMP Negeri 2 Wadaga Kabupaten Muna Barat dapat disimpulkan bahwa aspek penilaian menentukan struktur teks eksposisi yang terdiri dari tiga aspek yakni tesis, rangkaian argumen, dan penegasan kembali tidak ada yang mencapai kriteria ketuntasan klasikal yaitu $85 \%$. Berdasarkan hasil penelitian dengan menggunakan observasi dan angket menunjukan bahwa faktor-faktor berdasarkan kenyataan di lapangan mempengaruhi hasil belajar memiliki pengaruh terhadap hasil belajar siswa kelas VIII dengan faktor internal aspek motivasi yang merupakan persentase terbanyak dengan 78,43\%. Kata kunci: Kemampuan; Memahami; Teks Eksposisi; SMP N 2 Wadaga.
\end{abstract}

Kata Kunci : Kemampuan Menelaah, Struktur, Kaidah Kebahasaan, Teks Deskripsi

580 | Jurnal BASTRA (Bahasa dan Sastra), Vol. 4 No.4, Edisi Oktober 2019/e-ISSN: 25033875/http://ojs.uho.ac.id/index.php/BASTRA 


\begin{abstract}
Ability to Understand the Content of Exposition Texts of Class VIII Students of SMP Negeri 2 Wadaga Barat Muna Regency "This study is important to look back at the ability of students whether they have been able to absorb the material to understand the contents of the exposition text or not. The purpose of this study was to describe the ability to understand the contents of the exposition text of eighth grade students of SMP Negeri 2 Wadaga, West Muna Regency. This type of research belongs to school research because researchers go directly to the study site (school) to collect data in accordance with the research problem. The population in this study were all eighth grade students of SMP Negeri 2 Wadaga, West Muna Regency, which consisted of 51 students, spread in 2 classes. And the sample in this study were all eighth grade students of SMP Negeri 2 Wadaga, West Muna Regency. The data collection technique used in this study is a form of written essay test, namely by assigning students to understand the contents of the exposition text that has been read. The results of this study indicate that of the 51 respondents of VIII grade students of SMP Negeri 2 Wadaga, West Muna Regency, there were 39 students $(76.47 \%)$ in the category of being able to individually understand the contents of the exposition text, and as many as 12 students $(23.52 \%)$ is not able to understand the contents of the exposition text. Classically, it can be said that the ability to understand the contents of the exposition text of eighth grade students of SMP Negeri 2 Wadaga, West Muna Regency is not yet classically capable. It was said so because the ability of students only reached $76.47 \%$ had not yet reached the classical co.
\end{abstract}

Keywords: Ability; Understand; Exposition Text; SMP N 2 Wadaga.

581 | Jurnal BASTRA (Bahasa dan Sastra), Vol. 4 No.4, Edisi Oktober 2019/e-ISSN: 25033875/http://ojs.uho.ac.id/index.php/BASTRA 


\section{PENDAHULUAN}

Diberlakunya kurikulum 2013 sebagai pengembangan berbagai kompetensi tentu diperlukan demi pembinaan manusia (siswa) yang cerdas, jujur, disiplin dan berakhlak mulia, termaksud kompetensi membaca.Manusia (siswa) merupakan makhluk sosial yang selalu berhubungan dengan manusia lain. Untuk menjalin hubungan tersebut diperlukan suatu sarana, yaitu bahasa.Pada hakikatnya, fungsi utama bahasa adalah sebagai alat komunikasi. Oleh karena itu, pembelajaran bahasa dan sastra Indonesia diarahkan agar siswa terampil berkomunikasi, baik lisan maupun tulisan.Pembelajaran bahasa Indonesia selain untuk meningkatkan keterampilan berbahasa, juga untuk meningkatkan kemampuan berfikir, mengungkapkan gagasan ide, perasaan, dan pendapat.

Teks dalam bahasa Indonesia terbagi kedalam beberapa jenis dan setiap teks memiliki ciri-ciri yang berbeda. Untuk membedakan jenis-jenis teks dapat dilihat dari struktur teksnya. Karangan dapat disajikan dalam lima bentuk atau ragam wacana, antara lain; karangan narasi, karangan deskripsi, karangan eksposisi, karangan argumentatif, karangan persuasif.

Suatu hal yang sangat berbeda dengan kurikulum 2013 yang sepenuhnya berbasis teks dengan struktur berpikir antarsatu teks dengan teks lainya berbeda, karena fungsi sosial yang diemban setiap teks berbeda. Dengan kata lain, kurikulum 2013 sepenuhnya mendasarkan diri pada pendekatan lingistik sistemik fungsional. Ada beberapa alasan yang dapat dikemukakan mengenai teks yang dijadikan basis dalam pembelajaran kurikulum 2013.Pertama, melalui teks kemampuan berpikir siswa dapat dikembangkan; kedua, materi pembelajaran berupa teks lebih relevan dengan karakteristik kurikulum 2013 yang menetapkan capaian kompetensi siswa yang mencakupi ketiga ranah pendidikan: pengetahuan, keterampilan, dan sikap.

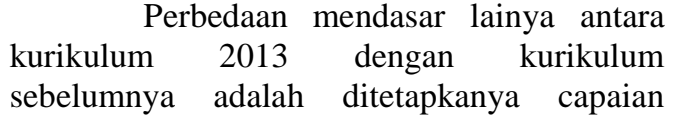

kompetensi siswa baik menyangkut kompetensi inti (KI) atas empat ranah: sikap spiritual, sikap sosial, pengetahuan, dan keterampilan. Penetapan empat ranah kompetensi tersebut sangat relevan dengan konsep teori linguistik tentang teks.Mengungkapkan bahwa kurikulum ialah suatu gagasan pendidikan yang diekspresikan melalui praktik.Dari pendapat tersebut dapat disimpulkan mengenai cara belajar siswa semakin berkembang dengan kurikulum 2013 sehingga siswa mampu melaksanakan pembelajaran di kelas dengan baik.

Ada beberapa teks yang dipelajari siswa SMP materi kurikulum 2013.Pada jenjang SMP, teks yang dipelajari ada 13 macam teks.Namun, ada beberapa teks yang memiliki persamaan di strukturnya.Dalam pembelajaran teks tidak hanya menyangkut dimensi bahasanya saja yang diajarkan tetapi juga situasi sosial yang merefleksi kondisi nilai-nilai yang melatarbelakangi munculnya teks harus diajarkan.Adanya muatan nilai-nilai itulah, pembelajaran teks, secara konsep keilmuwan, sesuai dengan rumusan kompetensi dalam kurikulum 2013.Kesesuaian tersebut menyangkut pula dimensi metodogi, khususnya terkait dengan metode pembelajaran teks yang dimulai dari kegiatan pemodelan, bekerja sama menghasilkan teks, dan kerja mandiri menghasilkan teks.

Sebagai contoh teks eksposisi yang memiliki fungsi sosial yang menjelaskan informasi-informasi pengetahuan dengan gaya informasi yang mengajak, bersifat informatif yang singkat, padat, dan akurat. Dalam proses pembelajaran teks sebelum dipaparkan ihwal keterhubungan antara pemeranan bahasa sebagai penghela ilmu pengetahuan sesuai dengan pembelajaran bahasa berbasisteks terlebih dahulu akan dijelaskan konsep penghela itu sendiri.

Pembelajaran bahasa Indonesia dalam kurikulum 2013 diarahkan agar para siswa memiliki keterampilan berbahasa dalam berbagai kegiatan sosial, keterampilan berbahsa yang dimaksud adalah siswa mampu mengamati, menanya, mengeksplorasikan, dan mengasosiasikan. Kompetensi dasar (KD) dalam pembelajaran bahasa Indonesia 
kurikulum 2013 dikembangkan berdasarkan yang saling berhubungan dan saling mendukung dalam mengembangkan pengetahuan siswa, memahami, dan memiliki komoetensi mendengarkan, membaca, berbicara, dan menulis. Ketiga hal tersebut adalah bahasa (pengetahuan tentang bahasa Indonesia), serta (memahami, mengapresiasi, menangkapi, menganalisis, dan menciptakan karya sastra; literasi (memperluas kompetensi bahasa Indonesia dalam berbagai tujuan khususnya yang berkaitan dengan membaca dan menulis.

Kurikulum2013 dikembangkan dengan penyempurnaan pola belajar sendiri dan kelompok dengan tetap memperhatikan pengembangan potensi khusus yang dimiliki setiap siswa.Salah satunya adalah kemampuan siswa dalam memahami berbagai macam isi teks dalam pembelajaran Bahasa Indonesia. Sesuai dengan kompetensi dasar mata pelajaran Bahasa Indonesia yang harus dikuasai oleh siswa kelas VIII SMP Negeri 2 Wadaga Kabupaten Muna Barat salah satunya mengenai pemahaman isi teks eksposisi sesuai dengan karakteristik teks yang akan diproduksi baik secara lisan maupun tulisan.

Berbicara mengenai teks eksposisi yang diajarkan di sekolah menengah pertama khususnya siswa kelas VIII SMP Negeri 2 Wadaga Kabupaten Muna Barat tentunya sangat erat hubunganya dengan pelajaran bahasa.Sama halnya dengan teks -teks lain, teks eksposisi juga mempunyai ciri-ciri khusus, struktur kalimat,contoh, dan lain sebagainya yang membedakan teks ini dengan teks yang lainya.

Dari permasalahan diatas, peneliti tertarik untuk mengadakan penelitian tentang menelaah isi teks eksposisi dengan judul "Kemampuan Memahami Isi Teks Eksposisi Siswa Kelas VIII SMP Negeri 2 Wadaga Kabupaten Muna Barat" penelitian memilih menelaah isi teks eksposisi sebagai objek peneltian, berdasarkan pertimbangan bahwa materi tersebut telah diajarkan dikelas VIII SMP Negeri 2 Wadaga Kabupaten Muna Barat.

Berdasarkan latar belakang, masalah dalam penelitian ini, yakni:
1. Bagaimanakah kemampuan memahami struktur teks eksposisi siswa kelas VIII SMP Negeri 2 WadagaKabupaten Muna Barat?

2. Faktor-faktor apa saja yang mempengaruhi hasil belajar siswa kelas VIII SMP Negeri 2 Wadaga Kabupaten Muna Barat?

Berdasarkan rumusan masalah, tujuan dari penelitian ini yakni:

1. Untuk mendeskripsikan kemampuan memahami struktur teks eksposisi siswa kelas VIII SMP Negeri 2 Wadaga Kabupaten Muna Barat.

2. Untuk mendeskripsikan faktor-faktor apa saja yang mempengaruhi hasil belajar siswa kelas VIII SMP Negeri 2 Wdaga Kabupaten Muna Barat

Manfaat yang diharapkan dalam penelitian ini adalah sebagai berikut:

1. Sebagai bahan masukan dalam pengembangan mutu pengajaran Bahasa Indoneisa, khususnya kelas VIII SMP Negeri 2 Wadaga Kabupaten Muna Barat.

2. Menjadi bahan informasi bagi guru bahasa Indonesia yang mengajar di Kelas VIII SMP Negeri 2 Wadaga Kabupaten Muna Barat.

3. Menjadi motivasi bagi siswa kelas VIII SMP Negeri 2 Wadaga Kabupaten Muna Barat dalam meningkatkan prestasi belajar Bahasa Indonesia, khususnya dalam memahami pelajaran isi teks eksposisi.

4. Sebagai bahan rujukan bagi penelitian selanjutnya yang relevan dengan penelitian ini.

Untuk menghindari terjadinya salah pengertian ada beberapa istilah yang perlu dijelaskan:

1. Kemampuan adalah kapasitas individu untuk melakukan beragam tugas dalam suatu pekerjaan.

2. Memahami yang dimaksud dalam penelitian ini adalah kegiatan yang dilakukan oleh siswa untuk 
memperoleh informasi yang disampaikan dari bacaan teks eksposisi.

3. Teks eksposisi adalah sebuah karangan atau paragraf yang mengandung informasi atau pengetahuan yang mencoba digambarkan dalam bentuk yang padat, singkat,dan jelas.

4. Struktur teks eksposisi adalah suatu tatanan yang membentuk suatu kelompok dalam sebuah teks.

5. Faktor internal adalah faktor yang berasal dari dalam diri seseorang atau individu itu sendiri.

6. Faktor eksternal adalah faktor yang berasal dari luar diri seseorang atau individu itu sendiri.

\section{METODE DAN TEKNIK PENELITIAN}

Jenis dan Metode Penelitian

Metode yang digunakan dalam penelitian ini adalah deskriptif kuantitatif. Deskriptif kuantitatif yaitu penelitian berusaha menyajikan kenyataan dilapangan secara objektif berkaitan dengan kemampuan memahami isi teks eksposisi siswa kelas VIII SMP Negeri 2 Wadaga Kabupaten Muna Barat dan faktor-faktor yang mempengaruhi hasil belajar siswa kelas VIII SMP Negeri 2 Wadaga Kabupaten Muna Barat dan selanjutnya diuraikan dengan menggunakan angka-angka bedasarkan prinsip-prinsip statistik.

Jenis penelitian ini adalah penelitian sekolah yaitu penelitian yang dilakukan secara langsung di sekolah yang menjadi objek atau tempat penelitian untuk memperoleh data penelitian.

Populasi dan Sampel Penelitian

Populasi penelitian ini adalah seluruh siswa kelas VIII SMP Negeri 2 Wadaga Kabupaten Muna Barat yang terdaftar pada tahun ajaran 2018/2019. Populasi berjumlah 51 orang yang terbagi dalam dua kelas yaitu VIII A sebanyak 25 siswa, VIII B sebanyak 26 orang siswa.

Penentuan sampel penelitian ini dilakukan dengan menggunakan teknik total sampling yaitu dengan cara memilih seluruh siswa kelas VIII SMP Negeri 2 Wadaga Kabupaten Muna Barat untuk menjadi responden. Hal ini sesuai dengan pendapat Arikunto (2002: 112) apabila subjeknya kurang dari 100 lebih baik diambil semua sehingga penelitianya merupakan penelitian populasi.Oleh karena itu, sampel penelitian diambil keseluruhan siswa kelas VIII (VIII A, VIII B,). Jika sebjek penelitianya lebih dari 100 orang, maka lebih baik diambil antara $10-$ $15 \%$ atau $20-25 \%$ atau lebih tergantung situasi, kondisi, dan kebutuhan. Dengan demikian, yang menjadi sampel penelitian ini adalah seluruh siswa kelas VIII SMP Negeri 2 Wadaga Kabupaten Muna Barat tahun ajaran 2018/2019 yang berjumlah 51 orang siswa.

Intrumen Penelitian Instrumen yang digunakan dalam penelitian ini adalah bentuk esai tes kemampuan memahami strktur teks eksposisi. Peneliti menyiapkan sebuah teks eksposisi yang bersumber dari buku.Teks eksposisi yang telah disiapkan dan dibagikan adalah teks eksposisi yang berasal luar daerah dengan alasan bahwa unsur-unsur yang terkandung dalam teks eksposisi tersebut masih asing bagi siswa karena jarang didengar. Siswa membaca teks eksposisi yang dibagikan untuk menjawab pertanyaan yang telah diberikan dalam lembar jawaban.Siswa diberikan waktu 2 x 40 menit untuk menjawab pertanyaan-pertanyaan tersebut berdasarkan teks eksposisi yang telah diberikan.

Instrumen yang digunakan untuk mengetahui faktor-faktor yang mempengaruhi hasil belajar siswa berdasarkan kenyataan di lapangan adalah observasi dan angket. Angket yang digunakan adalah jenis angket tertutup yaitu, seutu angket yang pertanyaan/pernyataan dan alternativ jawabanya telah ditentukan sehingga responden tinggal memilih jawaban yang diinginkan. Butir angket dinyatakan dalam dua bentuk, yakni pernyataan yang bersifat positif dan pernyataan yang bersifat negatif.Data mengenai faktor-faktor yang mempengaruhi hasil belajar diperoleh melalui angket skala likert. 
Teknik Pengumpulan Data

Teknik pengumpulan data yang digunakan dalam penelitian ini dalam bentuk tes esai tertulis, yaitu dengan menugaskan siswa untuk menelaah struktur teks eksposisi yang telah dibaca. Pada saat siswa membaca teks eksposisi, siswa membaca teks eksposisi agar siswa mampu menangkap struktur dari teks eksposisi yang dibaca serta mampu mengungkapkan kembali dalam bentuk tulisan dengan baik. Setelah membaca teks eksposisi selesai siswa diberi waktu untuk menjawab soal yang telah disediakan dengan alokasi waktu 2 x 40 menit. Sebelum soal diberikan, peneliti terlebih dahulu menjelaskan petunujuk penulisan menelaah isi teks eksposisi kepada responden sesuai dengan ketentuan yang termuat pada penjelasan instrumen.

Teknik pengumpulan data yang digunakan untuk mengetahui faktor-faktor berdasarkan kenyataan di lapangan yang mempengaruhi hasil belajar siswa kelas VIII SMP Negeri 2 Wadaga Kabupaten Muna Barat yaitu instrumen observasi dan angket:

a. Observasi, digunakan untuk mengamati hal-hal yang berhubungan dengan faktorfaktor yang mempengaruhi hasil belajar siswa.

b. Angket, digunakan untuk mencari data faktor-faktor yang mempengaruhi prestasi belajar siswa sehubungan dengan faktor psikologi, dan faktor sekolah. Halhal yang dikemukakan dalam angket tersebut adalah 4 item berhubungan dengan faktor psikologi siswa (internal) 4 item berhubungan dengan faktor sekolah siswa (eksternal).

Teknik Penilaian

Teknik untuk menilai tulisan siswa adalah teknik analitik, yaitu penilaian berdasarkan unsur-unsurnya. Skala yang dipakai untuk menilai tulisan adalah skala 1-4. Karena skala tersebut mengacu pada pedoman dan penskoran kemampuan memahami struktur teks eksposisi yang ditetapkan oleh Kementrian Pendidikan dan Kebudayaan (2017) sebagai berikut:

Dalam skala ini menggunakan skala penskoran yang dimaksud skala penskoran dalam teknik penilaian ini adalah jika siswa menjawab dengan benar maka siswa akan mendapat nilai 4 dan jika siswa menjawab 3 maka siswa mendapat nilai 3 dan jika siswa menjawab 2 maka siswa mendapat nilai 2 dan jika siswa menjawab salah maka mendapat nilai 1.

Teknik Analisis Data

Analisis data pada penelitian ini menggunakan deskriptif kuantitatif dan deskriptif kualitatif. Deksriptif kuantitatif yaitu menggambarkan hasil penelitian berdasarkan kenyataan objektif yang diperoleh di lapangan kemudian mengolah data menggunakan angka-angka sesuai dengan prinsip statistik. Penelti mengumpulkan data berupa hasil tes memahami strktur teks eksposisi siswa kelas VIII SMP Negeri 2 Wadaga Kabupaten Muna Barat kemudian mengolah berdasarkan klasifikasi skor masing-masing siswa dan datadata tersebut dianalisis menggunakan teknik presentase untuk mengukur tingkat kemampuan siswa pada setiap aspek yang diujikan baik secara individual maupun secara klasikal.

Seorang siswa dikatakan mampu secara individual jika mencapai Kriteria Ketuntasan Maksimal (KKM) 70\% dari setiap aspek yang dinilai.Sedangkan secara klasikal seorang siswa dikatakan mampu apabila memiliki ketuntasan belajar $85 \%$ dari setiap aspek yang dinilai.Hal ini sesuai dengan standar ketuntasan yang digunakan di SMP Negeri 2 Wadaga Kabupaten Muna Barat.

Untuk mengetahui kemampuan individual maka akan digunakan rumus membagi perolehan siswa dengan skor maksimal dikalikan dengan $100 \%$ yaitu sebagai berikut:

diperoleh $x 100 \%$

KIJumlah skor yang

Keterangan:

Jumlah skor maksimal

KI: Kemampuan individual

$\mathrm{KK}=\underline{\mathrm{Jumlah}}$ responden yang secara individual memperoleh nilai $\geq 70 \% \times 100 \%$ Jumlah seluruh responden

Keteranngan:

KK: Kemampuan klasikal

585 | Jurnal BASTRA (Bahasa dan Sastra), Vol. 4 No.4, Edisi Oktober 2019/e-ISSN: 25033875/http://ojs.uho.ac.id/index.php/BASTRA 
Menentukan kemampuan memahami struktur teks eksposisi pada siswa kelas VIII SMP Negeri 2 Wadaga Kabupaten Muna Barat digunakan sebagai berikut:

Tabel 2.1

Rentang Kemampuan

\begin{tabular}{lcl}
\hline $\begin{array}{l}\text { Rentang } \\
\text { Kemampuan }\end{array}$ & Skor & $\begin{array}{l}\text { Presentase } \\
\text { Kemampuan }\end{array}$ \\
\hline Mampu & $9-12$ & $75 \%-100 \%$ \\
\hline Tidak Mampu & $1-8$ & $8,33 \%-66,66 \%$ \\
\hline
\end{tabular}

Berdasarkan table diatas, maka dapat dijelaskan sebagai berikut:

1. Siswa dikatakan mampu dalam memahami strktur teks eksposisi kelas VIII SMP Negeri 2 Wadaga apabila mencapai skor 9-12dengan tingkat kemampuan responden $75 \%-100 \%$

2. Siswa dikatakan belum mampu dalam memahami struktur teks eksposisi siswa kelas VIII SMP Negeri 2 Wadaga apabila mencapai skor 1-8dengan presentase kemampuan $8,33 \%$ $66,66 \%$.

Rumus yang digunakan untuk menghitung frekuensi dari jawaban yang diberikan responden, untuk mendapatkan persentasi jawaban dari responden mengenai faktor-faktor yang mempengaruhi hasil belajar siswa, yaitu:

$$
\mathrm{P}=\frac{\text { frekuensi (f) }}{\text { jumlah responden }(\mathrm{N})} \times 100 \%
$$

Keterangan:

$\mathrm{P} \quad=$ Persentase hasil yang diperoleh

$\mathrm{f}=$ Frekuensi hasil yang diperoleh

$\mathrm{N}=$ Jumlah responden yang dijadikan sampel

$100 \%=$ Angka tetap persentasi

\section{HASIL PENELITIAN DAN}

PEMBAHASAN

2.1 Deskripsi Data Hasil Penelitian
Kemampuan Memahami Struktur Teks Eksposisi Siswa Kelas VIII SMP Negeri 2 Wadaga Kabupaten Muna Barat

Tabel 2.2

Kemampuan Memahami Struktur Teks Eksposisi Siswa Kelas VIII SMP Negeri 2 Wadaga Kabupaten Muna Barat

\begin{tabular}{ccccc}
\hline $\begin{array}{c}\mathrm{N} \\
\mathrm{o}\end{array}$ & $\begin{array}{c}\text { Katego } \\
\text { ri }\end{array}$ & $\begin{array}{c}\text { Frekuen } \\
\text { si }\end{array}$ & \multicolumn{2}{c}{$\begin{array}{c}\text { Ni } \\
\text { Persenta } \\
\text { se }\end{array}$} \\
\hline 1 & $\begin{array}{c}\text { Mamp } \\
\mathrm{u}\end{array}$ & 28 & 54,90 & $54,90 \%$ \\
& & & \\
\hline 2 & $\begin{array}{c}\text { Belum } \\
\text { Mamp } \\
\end{array}$ & 23 & 45,09 & $45,09 \%$ \\
& $\mathrm{u}$ & & \\
\hline & Jumlah & 51 & 100 & $100 \%$ \\
\hline
\end{tabular}

Selanjutnya untuk mengukur kemampuan siswa kelas VIII SMP Negeri 2 Wadaga Kabupaten Muna Barat dalam memahami struktur teks eksposisi secara klasikal maka digunakan rumus sebagai berikut.

$\mathrm{KK}=\underline{\text { Jumlah siswa yang memperoleh nilai }}$ dengan presentase $\times 100 \%$

Jumlah keseluruhan siswa

$=\frac{39}{51} \times 100 \%$

$=76,47 \%$

Dengan demikian, kemampuan memahami struktur teks eksposisi siswa kelas VIII SMP Negeri 2 Wadaga Kabupaten Muna Barat dikategorikan mampu secara individual. Dikatakan mampu karena siswa yang mencapai kemampuan individual melebihi $70 \%$ yakni mencapai $76,47 \%$ tetapi tidak mencapai kriteria ketuntasan klasikal $85 \%$.

\subsection{Deskripsi Kemampuan Memahami Struktur Teks Eksposisi Pada Setiap Aspek Penilaian \\ 2.2.1 Deskripsi Aspek Kemampuan Menentukan Tesis Dalam Struktur Teks Eksposisi}

Berdasarkan hasil pengolahan data tentang kemampuan memahami struktur teks

586 | Jurnal BASTRA (Bahasa dan Sastra), Vol. 4 No.4, Edisi Oktober 2019/e-ISSN: 25033875/http://ojs.uho.ac.id/index.php/BASTRA 
eksposisi dalam menentukan struktur teks eksposisi pada aspektesis menunjukkan bahwa dari 51 orang siswa kelas VIII SMP Negeri 2 Wadaga Kabupaten Muna Barat, sebanyak 34 orang siswa $(66,66 \%)$ yang secara individual masuk kategori mampu. sebanyak 17 orang siswa $(33,33 \%)$ yang secara individual masuk kategori belum mampu. Untuk lebih jelasnya dapat dilihat pada tabel berikut.

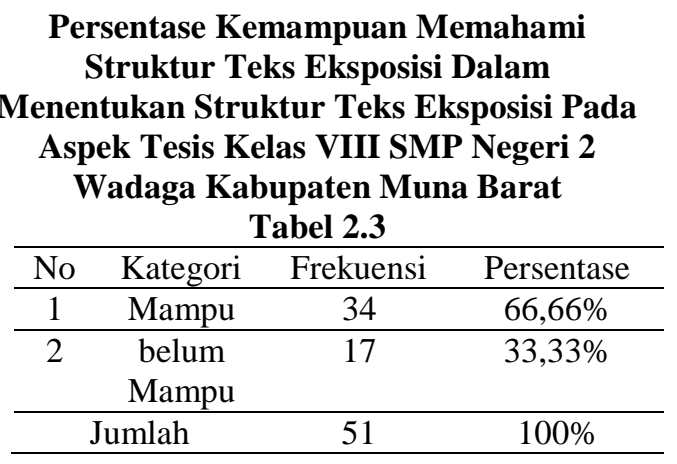

Dengan demikian, bila dilihat dari kemampuan memahami struktur teks eksposisi siswa kelas VIII SMP Negeri 2 Wadaga Kabupaten Muna Barat pada aspek penilain menentukan tesis dalam struktur teks eksposisi secara klasikal masuk kategori belum mampu, karena kriteria kemampuan klasikal adalah $85 \%$ sedangkan kemampuan secara klasikal siswa belum ada yang mampu atau mencapai $66,66 \%$.

\subsubsection{Deskripsi Aspek Kemampuan Menentukan Rangkaian Argumen Dalam Struktur Teks Eksposisi}

Berdasarkan hasil pengolahan data tentang kemampuan memahami struktur teks eksposisi pada aspek penilain menentukan rangakain argumendalam struktur teks eksposisi menunjukkan bahwa dari 51 orang siswa kelas VIII SMP Negeri 2 Wadaga Kabupaten Muna Barat, sebanyak 36 orang siswa $(70,58 \%)$ yang secara individual masuk kategori mampu sebanyak 15 orang siswa $(29,41 \%)$ dikategorikan belum mampu. Untuk lebih jelasnya dapat dilihat pada tabel berikut.

Persentase Kemampuan Memahami Struktur Teks Eksposisi Pada Aspek

\begin{tabular}{|c|c|c|c|}
\hline \multicolumn{4}{|c|}{$\begin{array}{c}\text { Penilain Menentukan Rangkaian Argumen } \\
\text { Dalam Struktur Teks EkspsisiSiswa Kelas } \\
\text { VIII SMP Negeri } 2 \text { Wadaga Kabupaten } \\
\text { Muna Barat } \\
\text { Tabel } 2.4\end{array}$} \\
\hline No & Kategori & Frekuensi & Persentase \\
\hline 1 & Mampu & 36 & $70,58 \%$ \\
\hline 2 & $\begin{array}{l}\text { Belum } \\
\text { Mampu }\end{array}$ & 15 & $29,41 \%$ \\
\hline & umlah & 51 & $100 \%$ \\
\hline
\end{tabular}

Dengan demikian, bila dilihat dari kemampuan memahami struktur teks eksposisi pada aspek penilain menentukan rangakaian argumendalam Struktur teks eksposisi secara klasikal masuk kategori belum mampu, karena kriteria kemampuan klasikal adalah $85 \%$ sedangkan kemampuan secara klasikal yang dicapai siswa hanya $70,58 \%$.

\subsubsection{Deskripsi Aspek Kemampuan Menentukan Penegasan Kembali Dalam Struktur Teks Eksposisi}

Berdasarkan hasil pengolahan data tentang kemampuan memahami isi teks eksposisi dalam struktur teks eksposisi pada aspekpenegasan kembali menunjukkan bahwa dari 51 orang siswa kelas VIII SMP Negeri 2 Wadaga Kabupaten Muna Barat, sebanyak 38 orang siswa $(74,50 \%)$ yang secara individual masuk kategori mampu. Sebanyak 13 orang siswa $(25,49 \%)$ dikategorikan belum mampu. Untuk lebih jelasnya dapat dilihat pada tabel berikut.

Persentase Kemampuan Memahami
Struktur Teks Eksposisi Pada Aspek Penilaian Menentukan penegasan kembali Dalam Struktur Teks Eksposisi Siswa Kelas VIII SMP Negeri 2 Wadaga Kabupaten Muna Barat

Tabel 2.5

\begin{tabular}{cccc}
\hline No & Kategori & Frekuensi & Persentase \\
\hline 1 & Mampu & 38 & $74,50 \%$ \\
\hline 2 & $\begin{array}{c}\text { Belum } \\
\text { Mampu }\end{array}$ & 13 & $25,49 \%$ \\
\hline \multicolumn{2}{c}{ Jumlah } & 51 & $100 \%$ \\
\hline
\end{tabular}

Dengan demikian, bila dilihat dari

587 | Jurnal BASTRA (Bahasa dan Sastra), Vol. 4 No.4, Edisi Oktober 2019/e-ISSN: 25033875/http://ojs.uho.ac.id/index.php/BASTRA 
kemampuan memahami struktur teks eksposisi pada aspek penilain menentukan penegasan kembali dalam Struktur teks eksposisi secara klasikal masuk kategori belum mampu, karena kriteria kemampuan klasikal adalah 85\% sedangkan kemampuan secara klasikal yang dicapai siswa hanya $74,50 \%$.

\subsection{Deskripsi Faktor-Faktor Yang} Mempengaruhi Hasil Belajar Siswa Kelas VIII SMP Negeri 2 Wadaga Kabupaten Muna Barat

\subsubsection{Faktor Internal Siswa}

1. Faktor Psikologi

Motivasi

\section{Merasa Senang Ketika Pembelajaran Bahasa Indonesia Berlangsung} Tabel 2.6

\begin{tabular}{cccc}
\hline $\begin{array}{c}\text { Kategor } \\
\mathrm{i} \\
\text { Jawaba } \\
\mathrm{n}\end{array}$ & $\begin{array}{c}\text { Frekuens } \\
\mathrm{i}(\mathrm{F})\end{array}$ & $\begin{array}{c}\text { Sko } \\
\mathrm{r}\end{array}$ & $\begin{array}{c}\text { Persentas } \\
\mathrm{e}\end{array}$ \\
\hline $\begin{array}{c}\text { Sangat } \\
\text { sering }\end{array}$ & 40 & 5 & $78,43 \%$ \\
\hline Sering & 11 & 4 & $21,56 \%$ \\
\hline $\begin{array}{c}\text { Kadang } \\
\text {-kadang }\end{array}$ & - & 3 & - \\
\hline Jarang & - & 2 & - \\
\hline $\begin{array}{l}\text { Sangat } \\
\text { jarang }\end{array}$ & - & 1 & - \\
\hline Jumlah & 51 & - & $100 \%$ \\
\hline
\end{tabular}

Dari tabel nampak 50 responden memperoleh skor 5 dengan persentase 98,03\% menyatakan sangat sering merasa senang ketika pembelajaran bahasa indonesia berlangsung, 1 responden memperoleh skor 4 dengan persentase $1,96 \%$ menyatakan sering merasa senang ketika pembelajaran bahasa indonesia berlangsung, tidak ada responden yang menyatakan kadang-kadang merasa senang ketika pembelajaran bahasa indonesia berlangsung, tidak ada responden yang menyatakan jarang merasa senang ketika pembelajaran bahasa indonesia berlangsung, tidak ada responden yang menyatakan sangat jarang merasa senang ketika pembelajaran bahasa indonesia berlangsung.

Minat

\section{Membaca Materi Pelajaran Bahasa Indonesia Ketika Pembelajaran Berlangsung \\ Tabel 2.7}

\begin{tabular}{cccc}
\hline $\begin{array}{c}\text { Kategori } \\
\text { Jawaban }\end{array}$ & $\begin{array}{c}\text { Frekuensi } \\
(\mathrm{F})\end{array}$ & Skor & Persentase \\
\hline $\begin{array}{c}\text { Sangat } \\
\text { sering }\end{array}$ & 8 & 5 & $15,68 \%$ \\
\hline Sering & 20 & 4 & $39,21 \%$ \\
\hline $\begin{array}{c}\text { Kadang- } \\
\text { kadang }\end{array}$ & 12 & 3 & $23,52 \%$ \\
\hline Jarang & 9 & 2 & $17,64 \%$ \\
\hline $\begin{array}{c}\text { Sangat } \\
\text { jarang }\end{array}$ & 2 & 1 & $3,92 \%$ \\
\hline Jumlah & 51 & - & $100 \%$ \\
\hline
\end{tabular}

Dari tabel nampak 8 responden memperoleh skor 5 dengan persentase 15,68\% menyatakan sangat seringMembaca materi pelajaran bahasa Indonesia ketika pembelajaran berlangsung, 20 responden memperoleh skor 4 dengan persentase 39,21\% menyatakan seringMembaca materi pelajaran bahasa Indonesia ketika pembelajaran berlangsung, 12 responden memperoleh skor 3 dengan persentase $23,52 \%$ menyatakan kadang-kadangMembaca materi pelajaran bahasa Indonesia ketika pembelajaran berlangsung, 9 responden memperoleh skor 2 dengan persentase $17,64 \%$ menyatakan jarang Membaca materi pelajaran bahasa Indonesia ketika pembelajaran berlangsung, 2 responden memperoleh skor 1 dengan persentase 3,92\% menyatakan sangat jarang membaca materi pelajaran bahasa Indonesia ketika pembelajaran berlangsung.

Bakat

\section{Merasa Kesulitan Dalam Memahami Materi yang di Ajarkan Oleh Guru} Tabel 2.8

\begin{tabular}{cccc}
\hline $\begin{array}{c}\text { Kategori } \\
\text { Jawaban }\end{array}$ & $\begin{array}{c}\text { Frekuensi } \\
(\mathrm{F})\end{array}$ & Skor & Persentase \\
\hline $\begin{array}{c}\text { Sangat } \\
\text { sering }\end{array}$ & 3 & 1 & $5,88 \%$ \\
\hline Sering & 5 & 2 & $9,80 \%$ \\
\hline $\begin{array}{c}\text { Kadang- } \\
\text { kadang }\end{array}$ & 14 & 3 & $27,45 \%$ \\
\hline Jarang & 17 & 4 & $33,33 \%$ \\
\hline
\end{tabular}




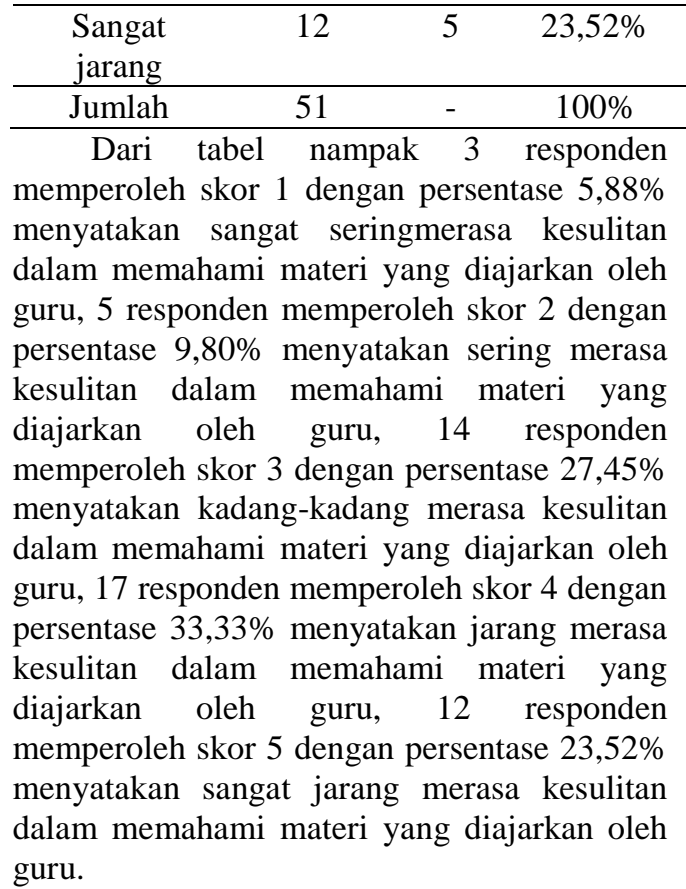

Rasa Percaya Diri

Memiliki tanggung jawab mengikuti pembelajaran bahasa Indonesia Tabel 2.9

\begin{tabular}{cccc}
\hline $\begin{array}{c}\text { Kategori } \\
\text { Jawaban }\end{array}$ & $\begin{array}{c}\text { Frekuensi } \\
(\mathrm{F})\end{array}$ & Skor & Persentase \\
\hline $\begin{array}{c}\text { Sangat } \\
\text { sering }\end{array}$ & 3 & 5 & $5,88 \%$ \\
\hline Sering & 31 & 4 & $60,78 \%$ \\
\hline $\begin{array}{c}\text { Kadang- } \\
\text { kadang }\end{array}$ & 13 & 3 & $25,49 \%$ \\
\hline Jarang & 4 & 2 & $7,84 \%$ \\
\hline $\begin{array}{c}\text { Sangat } \\
\text { jarang }\end{array}$ & - & 1 & - \\
\hline Jumlah & 51 & - & $100 \%$ \\
\hline Dari tabel nampak & 3 & responden
\end{tabular}
memperoleh skor 5 dengan persentase 5,88\% menyatakan sangat seringmemiliki tanggung jawab mengikuti pembelajaran bahasa indonesia, 18 responden memperoleh skor 4 dengan persentase $35,29 \%$ menyatakan seringmemiliki tanggung jawab mengikuti pembelajaran bahasa indonesia, 13 responden memperoleh skor 3 dengan persentase 25,49\% menyatakan kadang-kadangmemiliki tanggung jawab mengikuti pembelajaran bahasa indonesia, 4 responden memperoleh skor 2 dengan persentase $7,84 \%$ menyatakan jarangmemiliki tanggung jawab mengikuti pembelajaran bahasa indonesia, tidak ada responden yang menyatakan sangat jarangmemiliki tanggung jawab mengikuti pembelajaran bahasa indonesia.

\subsubsection{Faktor Eksternal Siswa}

1. Faktor Sekolah

Metode Mengajar

Merasa Bosan Ketika Guru Menggunakan Metode Ceramah

Tabel 2.10

\begin{tabular}{cccc}
\hline $\begin{array}{c}\text { Kategori } \\
\text { Jawaban }\end{array}$ & $\begin{array}{c}\text { Frekuensi } \\
(\mathrm{F})\end{array}$ & Skor & Persentase \\
\hline $\begin{array}{c}\text { Sangat } \\
\text { sering }\end{array}$ & - & 1 & - \\
\hline Sering & - & 2 & - \\
\hline $\begin{array}{c}\text { Kadang- } \\
\text { kadang }\end{array}$ & 4 & 3 & $7,84 \%$ \\
\hline Jarang & 10 & 4 & $19,60 \%$ \\
\hline $\begin{array}{c}\text { Sangat } \\
\text { jarang }\end{array}$ & 37 & 5 & $72,54 \%$ \\
\hline Jumlah & 51 & - & $100 \%$ \\
\hline
\end{tabular}

Dari tabel tidak ada responden yang menyatakan sangat seringmerasa bosan ketika guru menggunakan metode ceramah, tidak ada yang menyatakan sering merasa bosan ketika guru menggunakan metode ceramah, 4 responden memperoleh skor 3 dengan persentase $7,84 \%$ menyatakan kadang-kadang merasa bosan ketika guru menggunakan metode ceramah, 10 responden memperoleh skor 4 dengan persentase $19,60 \%$ yang menyatakan jarang merasa bosan ketika guru menggunakan metode ceramah, 37 responden memperoleh skor 5 dengan presentase 72,54\% yang menyatakan sangat jarang merasa bosan ketika guru menggunakan metode ceramah.

Kurikulum

\section{Fokus Terhadap Penjelasan Guru Pada Saat Pembelajaran Sedang Berlangsung Tabel 2.11}

\begin{tabular}{cccc}
\hline $\begin{array}{c}\text { Kategori } \\
\text { Jawaban }\end{array}$ & $\begin{array}{c}\text { Frekuensi } \\
(\mathrm{F})\end{array}$ & Skor & Persentase \\
\hline Sangat & 20 & 5 & $31,21 \%$ \\
\hline
\end{tabular}




\begin{tabular}{cccc}
\hline sering & & & \\
\hline Sering & 26 & 4 & $50,98 \%$ \\
\hline $\begin{array}{c}\text { Kadang- } \\
\text { kadang }\end{array}$ & 3 & 3 & $5,88 \%$ \\
\hline Jarang & 2 & 2 & $3,92 \%$ \\
\hline $\begin{array}{c}\text { Sangat } \\
\text { jarang }\end{array}$ & - & 1 & \\
\hline Jumlah & 51 & - & $100 \%$ \\
\hline
\end{tabular}

Dari tabel nampak 20 responden memperoleh skor 5 dengan persentase $31,21 \%$ menyatakan sangat seringfokus terhadap penjelasan guru pada saat pembelajaran sedang berlangsung, 26 responden memperoleh skor 4 dengan persentase 50,98\% menyatakan sering fokus terhadap penjelasan guru pada saat pembelajaran sedang berlangsung, 3 responden memperoleh skor 3 dengan persentase $5,88 \%$ menyatakan kadangkadangfokus terhadap penjelasan guru pada saat pembelajaran sedang berlangsung, 2 responden memperoleh skor 2 dengan persentase $3,92 \%$ menyatakan jarangfokus terhadap penjelasan guru pada saat pembelajaran sedang berlangsung, tidak ada responden yang menyatakan sangat jarang fokus terhadap penjelasan guru pada saat pembelajaran sedang berlangsung.

\section{Alat Pelajaran}

Terdapat Buku yang Menunjang Pembelajaran Bahasa Indonesia

Tabel 2.12

\begin{tabular}{|c|c|c|c|}
\hline $\begin{array}{l}\text { Kategori } \\
\text { Jawaban }\end{array}$ & $\begin{array}{l}\text { Frekuensi } \\
\text { (F) }\end{array}$ & Skor & Persentase \\
\hline $\begin{array}{l}\text { Sangat } \\
\text { sering }\end{array}$ & 24 & 5 & $47,05 \%$ \\
\hline Sering & 25 & 4 & $49,01 \%$ \\
\hline $\begin{array}{l}\text { Kadang- } \\
\text { kadang }\end{array}$ & 2 & 3 & $3,92 \%$ \\
\hline Jarang & - & 2 & \\
\hline $\begin{array}{l}\text { Sangat } \\
\text { jarang }\end{array}$ & - & 1 & \\
\hline Jumlah & 51 & - & $100 \%$ \\
\hline $\begin{array}{l}\text { Dari } \\
\text { memperoleh } \\
\text { yang menyat } \\
\text { yang men } \\
\text { indonesia, } 25 \\
\text { dengan prese }\end{array}$ & $\begin{array}{l}\text { bel nampa } \\
\text { kor } 5 \text { dengan } \\
\text { kan sangat } \\
\text { hjang pem } \\
\text { responden }\end{array}$ & $\begin{array}{l}24 \\
\text { presen } \\
\text { eringte } \\
\text { belajar } \\
\text { hemper } \\
\text { yang }\end{array}$ & $\begin{array}{r}\text { responden } \\
\text { ase } 47,09 \% \\
\text { dapat buku } \\
\text { n bahasa } \\
\text { leh skor } 4 \\
\text { menyatakan }\end{array}$ \\
\hline
\end{tabular}

seringterdapat buku yang menunjang pembelajaran bahasa indonesia, 2 responden memperoleh skor 3 dengan persentase 3,92\% menyatakan kadang-kadangterdapat buku yang menunjang pembelajaran bahasa indonesia, tidak ada responden yang menyatakan jarangterdapat buku yang menunjang pembelajaran bahasa indonesia, tidak ada responden yang menyatakan sangat jarang terdapat buku yang menunjang pembelajaran bahasa indonesia.

\section{Keadaan Gedung}

Gedung Dan Ruangan Kelas Terawat Untuk Menunjang Kegiatan Belajar 2.13

\begin{tabular}{|c|c|c|c|}
\hline $\begin{array}{l}\text { Kategori } \\
\text { Jawaban }\end{array}$ & $\begin{array}{l}\text { Frekuensi } \\
\text { (F) }\end{array}$ & Skor & Persentase \\
\hline $\begin{array}{c}\text { Sangat } \\
\text { sering }\end{array}$ & 26 & 5 & $50,98 \%$ \\
\hline Sering & 20 & 4 & $39,21 \%$ \\
\hline $\begin{array}{l}\text { Kadang- } \\
\text { kadang }\end{array}$ & 5 & 3 & $9,80 \%$ \\
\hline Jarang & - & 2 & - \\
\hline $\begin{array}{l}\text { Sangat } \\
\text { jarang }\end{array}$ & - & 1 & - \\
\hline Jumlah & 51 & - & $100 \%$ \\
\hline
\end{tabular}

Dari tabel tampak 26 responden memperoleh skor 5 dengan persentase 50,98\% menyatakan sangat sering gedung dan ruangan kelas terawat dan menunjang kegiatan belajar, 20 responden memperoleh skor 4 dengan persentase $39,21 \%$ yang menyatakan sering gedung dan ruangan kelas terawat dan menunjang kegiatan belajar, 5 responden memperoleh skor 3 dengan persentase 9,80\% yang menyatakan kadang-kadang gedung dan ruangan kelas terawat dan menunjang kegiatan belajar, tidak ada responden yang menyatakan jarang gedung dan ruangan kelas terawat dan menunjang kegiatan belajar, tidak ada responden yang menyatakan sangat tidak sering gedung dan ruangan kelas terawat dan menunjang kegiatan belajar.

\subsection{Pembahasan Dalam Penelitian Data Kemampuan Memahami Struktur Teks Eksposisi Siswa Kelas VIII SMP Negeri 2 Wadaga Kabupaten Muna Barat Rangkuman Data Kemampuan Memahami}

590 | Jurnal BASTRA (Bahasa dan Sastra), Vol. 4 No.4, Edisi Oktober 2019/e-ISSN: 25033875/http://ojs.uho.ac.id/index.php/BASTRA 


\begin{tabular}{|c|c|c|c|}
\hline \multicolumn{4}{|c|}{$\begin{array}{c}\text { Struktur Teks Eksposisi Siswa Kelas VIII } \\
\text { SMP Negeri } 2 \text { Wadaga Kabupaten Muna } \\
\text { Barat } \\
2.14\end{array}$} \\
\hline No & $\begin{array}{c}\text { Aspek } \\
\text { kemampuan }\end{array}$ & $\begin{array}{c}\text { Tingkat } \\
\text { Kemampuan }\end{array}$ & Kategori \\
\hline 1. & $\begin{array}{l}\text { Menentukan } \\
\text { Tesis } \\
\text { (Pernyataan } \\
\text { Pendapat) }\end{array}$ & 66,66 & $\begin{array}{l}\text { Belum } \\
\text { Mampu }\end{array}$ \\
\hline 2. & $\begin{array}{c}\text { Menentukan } \\
\text { Rangkaian } \\
\text { argument }\end{array}$ & 70,58 & $\begin{array}{l}\text { Belum } \\
\text { Mampu }\end{array}$ \\
\hline 3. & $\begin{array}{c}\text { Menentukan } \\
\text { Penegasan } \\
\text { Kembali }\end{array}$ & 74,50 & $\begin{array}{l}\text { Belum } \\
\text { Mampu }\end{array}$ \\
\hline
\end{tabular}

Untuk lebih jelasnya tentang kemampuan memahami isi teks eksposisi siswa kelas VIII SMP Negeri 2 Wadaga Kabupaten Muna Barat adalah sebagai berikut:

1. Dari hasil analisis kemampuan memahami struktur teks eksposisi siswa kelas VIII SMP Negeri 2 Wadaga Kabupaten Muna Barat dalam menentukan strktur teks eksposisi yang dibaca pada teks eksposisi yakni tesis, rangkaian argumen, dan penegasan kembali dapat dilihat sebagai berikut ini

a. Strktur teks eksposisi pada aspek tesis dapat dikatakan bahwa dari 51 orang siswa responden yang telah diteliti terdapat 34 orang siswa dinyatakan mampu dengan nilai 66,66 dan persentase $66,66 \%$ serta terdapat 17 orang siswa dinyatakan belum mampu dengan nilai dengan nilai 33,33 dan persentase $33,33 \%$. Secara kalsikal belum bisa dikatakan mampu karena persentase yang telah dicapai hanya $66,66 \%$ dan tidak mencapai ketuntasan klasikal yaitu $85 \%$.

b. Strktur teks eksposisi pada aspek rangkaian argumen dapat dikatakan bahwa dari 51 orang siswa responden yang telah diteliti terdapat 36 orang siswa dinyatakan mampu dengan nilai 70,58 dan persentase $70,58 \%$ serta terdapat 15 orang siswa dinyatakan belum mampu dengan nilai dengan nilai 29,41 dan persentase $29,41 \%$. Secara kalsikal belum bisa dikatakan mampu karena persentase yang telah dicapai hanya $70,58 \%$ dan tidak mencapai ketuntasan klasikal yaitu $85 \%$.

c. Strktur teks eksposisi pada aspek penegasan kembali dapat dikatakan bahwa dari 51 orang siswa responden yang telah diteliti terdapat 38 orang siswa dinyatakan mampu dengan nilai 74,50 dan persentase $74,50 \%$ serta terdapat 13 orang siswa dinyatakan belum mampu dengan nilai dengan nilai 25,49 dan persentase $25,49 \%$. Secara kalsikal belum bisa dikatakan mampu karena persentase yang telah dicapai hanya 43,13\% dan tidak mencapai ketuntasan klasikal yaitu $85 \%$.

\section{PENUTUP}

\section{Simpulan}

Berdasarkan hasil penelitian data yang dilakukan, dapat disimpulkan bahwa dari 51 responden siswa kelas VIII SMP Negeri 2 Wadaga Kabupaten Muna Barat, terdapat 39 orang siswa dengan nilai 76,47 dan persentase $(76,47 \%)$ masuk kategori mampu secara individual dalam memahami struktur teks eksposisi, dan sebanyak 12 orang siswa dengan nilai 23,52 dan persentase $(23,52 \%)$ masuk kategori belum mampu dalam memahami isi teks eksposisi. Secara klasikal dapat dikatakan bahwa kemampuan dalam memahami isi teks eksposisi masuk kategori belum mampu secara klasikal siswa kelas VIII SMP Negeri 2 Wadaga Kabupaten Muna Barat. Dikatakan demikian karena kemampuan siswa hanya mencapai $76,47 \%$ belum mencapai kriteria ketuntasan klasikal yaitu $85 \%$. Jika dilihat dari setiap aspek penilaian kemampuan siswa kelas VIII SMP Negeri 2 Wadaga Kabupaten Muna Barat dapat disimpulkan bahwa dalam menentukan struktur teks eksposisi pada tesis, rangkain argumen, dan penegasan kembali belum mencapai kriteria ketuntasan klasikal yaitu $85 \%$

Selain itu, berdasarkan data hasil penelitian yang dilakukan dapat disimpulkan faktor-faktor yang mempengaruhi hasil belajar Bahasa Indonesia siswa kelas

591 | Jurnal BASTRA (Bahasa dan Sastra), Vol. 4 No.4, Edisi Oktober 2019/e-ISSN: 25033875/http://ojs.uho.ac.id/index.php/BASTRA 
VIII SMP Negeri 2 Wadaga Kabupaten Muna Barat berdasarkan kenyataan di lapangan yang terdiri dari faktor psikologi (internal) sebanyak 4 aspek dan faktor sekolah (eksternal) sebanyak 4 aspek. Faktor internal siswa meliputi aspek motivasi, minat, bakat, dan rasa percaya diri. Aspek motivasi siswa dengan memperoleh skor $5(78,43 \%)$, dan skor 4 $(21,56 \%)$. Aspek minat siswa dengan memperoleh skor $5(15,68 \%)$, skor 4 $(39,21 \%)$, skor $3(23,52 \%)$, skor $2(17,64 \%)$, dan skor $1(3,92 \%)$. Aspek bakat siswa dengan memperoleh skor $1(5,88 \%)$, skor $2(27,45 \%)$, skor $3(33,33 \%)$, skor $4(23,52 \%)$, dan skor 5 $(9,80 \%)$. Aspek rasa percaya diri siswa dengan memperoleh skor 5 (5,88\%), skor $4(60,78 \%)$, skor $3(25,49 \%)$, skor $2(7,84 \%)$. Berdasarkan hasil penelitian faktor ekternal yang mempengaruhi prestasi belajar siswa yang meliputi aspek metode mengajar, kurikulum, alat pelajaran, keadaan gedung. Aspek metode mengajar siswa dengan memperoleh skor skor $3(7,84 \%)$, skor $4(19,60 \%)$, dan skor 5 $(72,54)$. Aspek kurikulum siswa dengan memperoleh skor $5(31,21 \%)$, skor $4(5,88 \%)$, skor $3(50,98 \%)$, dan skor $2(3,92 \%)$. Aspek alat pelajaran siswa dengan skor $5(47,05 \%)$, skor $4(49,01 \%)$, dan skor $3(3,92 \%)$. Aspek keadaan gedung siswa dengan skor 5 $(50,98 \%)$, skor $4(39,21 \%)$, dan skor 3 $(9,80 \%)$.

Dengan mengacu pada kemampuan siswa yang diperlihatkan dalam memahami struktur teks eksposisi dalam penelitian ini disarankan sebagai berikut.

1. Guru bahasa dan sastra Indonesia perlu memperhatikan secara khusus kepada siswa yang belum memiliki kemampuan berhubungan dengan aspek yang menjadi penilaian dalam memahami isi teks eksposisi.

2. Untuk pembelajaran memahami isi teks eksposisi, guru dapat menyesuaikan ketuntasan materi pembelajaran dengan pemahaman siswa sehingga yang menjadi keseluruhan aspek penilaian dapat dipahami atau dimengerti oleh siswa.
3. Dalam proses belajar mengajar sebaiknya guru mata pelajaran bahasa Indonesia perlu meningkatkan kemampuan siswa dengan mengoreksi atau meluruskan kekeliruan dalam menentukan struktur teks eksposisi serta melakukan adanya remedial untuk mengembangkan kemampuan siswa.

Dengan mengacu pada faktor-faktor yang mempengaruhi hasil belajar siswa kelas VIII SMP Negeri 2 Wadaga Kabupaten Muna Barat.

1. Siswa sebagai peserta didik hendaknya dapat lebih giat lagi dalam memahami materi pelajaran untuk meningkatkan hasil belajarnya di sekolah.

2. Guru sebagai pendidik hendaknya dapat mengetahui dan memahami karakteristik peserta didik agar dalam proses dan cara mendidik siswa lebih baik lagi. Selain itu guru juga hendaknya dapat menciptakan suasana belajar yang menyenangkan agar siswa lebih antusias dalam mengikuti proses pembelajaran di kelas sehingga hasil belajar siswa diharapkan dapat tercapai dengan optimal dan berjalan dengan baik.

\section{DAFTAR PUSTAKA}

Ahmad dan Alek. 2016. Bahasa Indonesia Untuk Perguruan Tinggi. Jakarta: Erlangga.

Arikunto, Suharsimi. 2002. Prosedur Penelitian Suatu Bentuk. Jakarta: PT RINGGA CIPTA.

Keraf, Gorys. 1995. Eksposisi. Jakarta: PT Grasindo.

Kosasih. 2017. Bahasa Indonesia SMP/MTS Kelas VIII. Jakarta: Kementrian Pendidikan.

Kosasih. 2018. Jenis-Jenis Teks Fungsi, Struktur, dan Kebahasaan Mata Pelajaran Bahasa Indonesia SMP/MTS. Bandung: Yrama Widya.

Kusmana, dkk. 2019. Cerdas Berbahasa. Bandung: Yrama Widya.

Mahsun. 2014. Teks Dalam Pembelajaran Bahasa Indonesia Kurikulum 2013. 
Jakarta: Rajawali Pers.

Nurhadi. 2016. Strategi Meningkatkan Daya

Baca. Jakarta: Bumi Aksara.

Nurhadi. 2016. Teknik Membaca. Jakarta:

Bumi Aksara.

Rosmayana, Elin. 2018. Pembelajaran Menulis Teks Eksposisi Dengan Menggunakan Pendekatan Kooperatif Tipe Investigasi Kelompok Di SMP. Jurnal Pendidikan Bahasa dan Sastra Indonesia Volume 5, nomor 1.

Rozak. 2016. Desain Bahan Ajar Teks Eksposisi Dan Implementasinya Pada Siswa Kelas X SMA/SMK. Jurnal Pendidikan Bahasa dan Sastra Indonesia Volume 3, nomor 1.

Saddhono. 2014. Pembelajaran Keterampilan Berbahasa Indonesia. Yogyakarta: Graha Ilmu.

Samniah, Naswiani. 2016. Kemampuan Memahami Isi Bacaan Siswa Kelas VII MTS SwastaLabibia. Jurnal Humanika Volume 1, nomor 16.

Sauhenda, Angla Florendi, dkk. 2016. Pengembangan Asesmen Penugasan Menulis Teks Eksposisi Dengan Rangsangan Masalah Autentik. Jurnal pendidikan Volume 1, nomor 3.

Tarigan, Hendry Guntur. 2008. Membaca Sebagai Keterampilan Berbahasa. Bandung: Angkasa.

Suwardi. 2012. Faktor-faktor Yang Mempengaruhi Hasil Belajar Siswa Kompetensi Dasar Ayat Jurnal Penyesuaian Mata Pelajaran Akutansi Kelas XI IPS di SMA NEGERI Bae Kudus. Jurnal Pendidikan Ekonomi Volume 1, nomor 2.

Titscher, Stefan, dkk. 2009. Metode Analisis Teks \& Wacana. Yogyakarta: Pustaka Pelajar. 